\title{
Bibliographical Services In the United States, 1950-1959
}

BY KATHRINE OLIVER MURRA

\section{Bibliographical Working Group}

The American Library Association in 1951 presented a five-year plan for a basic study of bibliographical organization. Its Committee on Bibliography was resuscitated to coordinate and develop the growing interest in bibliographical organization which had been highlighted the previous year by the University of Chicago's Graduate Library School's summer conference on the subject. This Committee and the successor to the UNESCO/Library of Congress Bibliographical Planning Group, the Librarian's Bibliographical Seminar, informally explored ways of bringing into being a United States Bibliographical Planning Group. In 1952, the ALA committee enlarged its membership by inviting members from other professional library and documentation organizations to work with it. The new committee was designated the U.S. Bibliographical Working Group to cooperate with UNEsco in 1953 and reconstituted as the ALA's Board on Bibliography. It began a survey of the status of bibliography in various fields. At this time plans were made to fill the gap in American bibliography from 1800-1820 by completing Evans and supplementing it. The results are reported under "National Bibliography."

A series of circumstances has retarded the progress of the committee in its national function. Leadership in the early years of the decade which was intensely interested in this work was drawn elsewhere; progress in the development of a program was hampered by a complete reorganization of ALA itself which affected all segments of the organization. The board became a committee; inter-
Mrs. Murra is Head, International Organizations Section, Reference Department, Library of Congress. This article was prepared for the decennial UNESCO review of bibliographical services throughout the world.

est in it dwindled or shifted to documentation and mechanization. It is gradually recovering and resuming its work.

\section{Library CoOperation}

Cooperative enterprise so permeates the structure of bibliographical life in the United States that evidences of it will be found throughout this report and not alone in this section.

During the second half of the decade one particularly significant catalyst of cooperation came into being. The Council on Library Resources, Inc. was created by the Ford Foundation and given \$5,000,000 to spend over a five year period "to aid, in the solution of library problems." Many of the most notable cooperative enterprises of this period have been supported in part or in whole by the Council.

Important examples of such Councilsupported programs are: A two year extension of the cooperative acquisition effort of some sixty libraries begun in 1947 to bring foreign materials into the country-the Farmington Plan; publication of a third and final edition of the Union List of Serials bringing it up to 1950 by reprinting in one alphabet the titles of the second edition and two supplements. A joint committee representing all segments of library work directs and supervises preparation by the Library of Congress. The third project is the prepa- 
ration of an American Milkau under the editorship of Ralph R. Shaw. A distinguished group of librarians and documentalists are working on the "State of the Library Art," and five volumes, or about 40 per cent of the complete work, have been published.

Regional bibliographical and storage centers which contribute directly to the national bibliographical control have been founded or have expanded their operations during this period. For example, the Southeastern Interlibrary Research Facility, the Hampshire Inter-Library Center, and the Inter-College-Hill Reference Library Cooperative, Inc. are new. The Midwest Inter-Library Center has expanded its membership beyond its region, is open to all university and research libraries in the country, has undertaken cooperative acquisition of journals indexed in Chemical Abstracts, has established a national foreign newspaper microfilm pool, and proposes to create also a national microfilm pool for negatives of books listed in Wing's Shorttitle Catalog. There has been an upsurge of cooperation among county, public, and school libraries in various parts of the country. A number of these feature centralized processing and/or acquisitions and union lists and catalogs. One of the most recent groups formed is the Southwest Missouri Library Service, Inc., with twenty-nine participating libraries.

Cooperative acquisitions programs are new to librarianship. The Farmington Plan, a pioneering effort in this direction, attains its thirteenth year in an expanded program. Sixty libraries have agreed "to make sure that at least one copy of each new foreign book and pamphlet that might conceivably interest a research worker in the United States will be acquired by an American library," and that they will be listed in the National Union Catalog and made available by loan or photocopy. The area of activity was divided by subjects among the libraries and limited to Western Europe. Some
150,000 volumes have been brought into the country under its auspices. Plans are being made to work also in other parts of the world.

Further pursuit of foreign materials through cooperative acquisitions efforts also has been accelerated through a Conference on American Library Resources in Southern Asia in 1957; a series of seminars on Latin American acquisition problems begun in 1956 under the auspices of the Pan American Union, the Library of Congress, and a number of universities with Latin American programs; the Slavic Studies Project in which eight libraries purchased Russian books in Moscow through the U. S. Department of State from 1950-1957; a cooperative acquisitions program and union list of foreign dental periodicals initiated by the American Dental Association, and others.

Major developments in the U. S. national bibliography mark this decade and are the result of extensive cooperation but will be noted subsequently.

Basic to a cooperative bibliographic record is agreement on cataloging rules. Librarians have been increasingly dissatisfied with the ALA code of 1949. Not until 1951, however, did the Board on Cataloging Policy and Research of the ALA Division of Cataloging and Classification commission Seymour Lubetzky to study the existing code with particular attention to rules for corporate authors, and objectives and principles. In 1953, Mr. Lubetzky's report was published as Cataloging Rules and Principles calling for a thorough revision of the code along specified lines which increased debate in the literature, at association meetings, and in special institutes. A Catalog Code Revision Committee probed interest in revision and the lines along which it should proceed. Mr. Lubetzky was then directed to work toward the revision in consultation with sub-committees established to deal with the more difficult problems. The revised code in prelimi- 
nary form was circulated in the spring of 1960 and is being widely discussed. Among other things, it is designed to contribute to the discussion of an international cataloging code at the International Cataloguing Conference scheduled for October of 1961 under the auspices of the International Federation of Library Associations, with money from the Council on Library Resources.

Achievement of standardization of bibliographical entries through uniform catalog rules is still questioned. Nevertheless, catalog rules have been agreed upon by a majority of users for books in Roman alphabets, Arabic and Oriental materials, motion pictures and filmstrips, books in raised characters, phonorecords, manuscripts, music.

A cooperative experiment to test the financial and technical possibility and usefulness of cataloging books prior to publication so that the cataloging information could be printed in the books by the publishers was recently concluded. In addition to the American Library Association and the Council on Library Resources, Inc., which financed the undertaking, those cooperating were 157 publishing concerns of all types, and more than two hundred libraries including the Library of Congress where the cataloging was done. The conclusion was that no full-scale program of Catalogingin-Source could be justified. Since the final report has appeared suggestions have been made for introduction of a more limited program. Many think pre-publication cataloging can further standardize bibliographical entries and reduce cataloging costs for small libraries.

The government of the United States has passed two pieces of legislation leading to cooperation of Federal and private agencies and libraries. One calls for programs for the use of counterpart funds to be prepared by the Library of Congress, the National Science Foundation, and others to analyze and evaluate foreign materials for usefulness to the
United States for the scientific and technical information they may contain; to register, index, bind, catalog, abstract, translate, and disseminate such works; and to acquire books, periodicals, and other materials for libraries and research centers in the U.S.A. All work must be done outside of this country.

The second law provided for the establishment of a Science Information Service in the National Science Foundation to arrange for abstracting, translating, and other services leading to a more effective dissemination of scientific information and to conduct programs to develop new or improved methods for making scientific information available. This service is serving to stimulate cooperation among scientists, documentalists, machine experts, and others.

Cooperation is not limited to that between libraries and others in this country or this continent. International library cooperation is rooted deeply in the last century. However the last decade has brought together more groups of greater diversification at more frequent intervals than ever before under international auspices both in this country and abroad.

\section{National Bibliography}

\section{Current}

In the United States there is no distinct entity that can be labelled "the current national bibliography." There is a collection of small and large works which may be considered fragments of this amorphous concept. Some large and valuable fragments have been added in the last ten years.

The decade is notable for the return of printed book catalogs. In 1956, the Library of Congress Catalog-Books: Authors (1948- ) was expanded to include entries for 1956 and later imprints sent to the National Union Catalog, and retitled The National Union Catalog, a Curnulative Author List Representing Library of Congress Printed Cards and 
Titles Reported by Other Libraries. It represents cooperation between the $\mathrm{Li}$ brary of Congress, the ALA's Committee on Resources of American Libraries, and more than five hundred libraries in the United States and Canada.

The National Library of Medicine began publishing a printed catalog of its current collections in 1950. The 1950-54 segment has been supplemented by the National Library of Medicine Catalog: A List of Works Represented by National Library of Medicine Cards 1955-1959. Part I contains the author list and Part II the subject. Each is in three volumes.

Work is under way in the Library of Congress on a national union catalog of Oriental serials in the vernacular.

In 1953, the Library of Congress Serial Titles Newly Received (1950- ) under the new title, New Serial Titles (monthly, annual cummulations) was inaugurated. A union list supplementing the Union List of Serials, it now receives titles and locations from more than four hundred cooperating libraries.

For many years the Cumulative Book Index and the "Weekly Record" appearing in Publishers' Weekly have been the chief listing of current U. S. book imprints. In February 1960 the publisher of the latter, R. R. Bowker Company, began issuing a monthly American Book Publishing Record with entries from the Library of Congress cataloging divisions arranged by Dewey Decimal Classification with author and title index and annotations. The listing is in many ways similar to the British National Bibliography-in composition of entry and in its potential use in an extensive cooperative acquisitions program. The same company is also publishing Books To Come which is an advance book reporting service appearing six times a year.

Other basic listings continuing in this decade are: Catalog of Copyright Entries (U. S. Copyright Office) in 13 parts; Monthly Catalog of United States Government Publications (U. S. Superintend- ent of Documents); N. W. Ayer \& Son's Directory: Newspapers and Periodicals; Publishers' Trade List Annuals; Monthly Checklist of State Publications (Library of Congress).

Two significant additions to a subject approach to the national bibliography are: Bowker's Subject Guide to Books in Print (1957- ) now in its third edition which indexes the Publishers' Trade List Annual, and Library of Congress Catalog-Books: Subjects (1950- ) which includes all books for which the Library prints cards whether of its own cataloging or that from cooperating libraries.

\section{RETROSPECTIVE}

Contributions of note to retrospective national bibliography are the issuance of volumes 13 and 14 of Evans's American Bibliography by the American Antiquarian Society in 1955 and 1959, respectively. Volumes yet to come are Roger Bristol's "Checklist of Titles Not in Evans" and a short title revision of the entire work. Ralph R. Shaw and a group of volunteers began work on a supplement to Evans to cover the period 1800 1820. Thus far a Preface to American Bibliography 1801-1819, volume I, and American Bibliography, A Preliminary Checklist, 1801-1805 (five of six volumes) have appeared. The New York Public Library has issued Checklist of Additions to Evans' American Bibliography in its Rare Book Division which contains short-titles of 1289 items.

The Bibliographical Society of America is engaged in revising Margaret Bingham Stillwell's Incunabula in American Libraries, which embraces Mexican, Canadian and U. S. libraries.

Work is well advanced on editing for publication the entries for 1952-1955 in the National Union Catalog. This involves removing duplicate entries resulting from divergent forms used among more than five hundred libraries submitting cards, and modifying entries which do not conform to ALA cataloging rules 
or Library of Congress practice. Since some 212,500 entries are main entry Library of Congress cards the task is feasible. The 1952-55 volume monographic material reported within those dates plus maps, atlases, microcards, and microfilm will contain approximately 560,000 entries. A third and final edition of the Union List of Serials, henceforth to be kept up to date by New Serial Titles, is in progress.

Thirty-six libraries, members or neighbors of the Association of Southeastern Research Libraries, have produced a Southeastern Supplement to the Union List of Serials largely with volunteer help. This work gives this region almost complete bibliographical control over its serials for the first time.

A National Union Catalog of Manuscript Collections is a growing reality on printed cards in the Library of Congress. Information has already been received from 40 repositories out of about 210 in the United States and Canada. Eventually an estimated 24,000 collections will be represented in the catalog. The first 263 cards had come from the press by the end of 1959 and an anticipated 3000 more will be issued in 1960 .

Specialized union lists and catalogs are too numerous to mention.

\section{TyPes of Material}

Rare books and manuscripts. The Rare Books Section of ACRL has before it in draft form $A$ Rare Book Manual, preliminary edition, edited by $\mathrm{H}$. Richard Archer of Williams College and other volunteers. It was authorized in response to a long felt need which found expression even before this new section was established.

Some programs of note other than those in the category of national bibliography are briefly described.

The microfilming of approximately thirty thousand codexes considered most important to scholarship in the Western Hemisphere in the Vatican Library was begun in 1957 by the library of Saint Louis University with a grant from the Knights of Columbus.

In 1951, the Modern Language Association began a survey of American literary manuscripts in American libraries which will result in a checklist showing location and quantity of holdings.

Marquette University is establishing an American Catholic Archives Center which will contain originals or microfilm copies of every Roman Catholic periodical, plus other material, ever published in America.

Manuscripts. The National Union Catalog of Manuscripts and agreement on Rules for Cataloging Manuscripts are probably the most significant achievements.

A program is being developed by four national organizations with the support of the National Science Foundation to provide for deposit of scientific manuscript collections in appropriate locations and their contents and location made known for the encouragement of scholarly investigation.

Government publications. The Congress of the United States passed a law which redefines a government publication "as informational matter which is published as an individual document at government expense or as required by law." The same law, prepared in conjunction with the ALA, revised the depository library to provide wider use of Federal Government publications.

The inquiry precedent to this law, embraced a survey of the adequacy of the Monthly Gatalog of United States Government Publications, the primary current bibliographical control of the field. Forty per cent of the 666 libraries replying to a questionnaire asked for improvements in coverage, indexing, and promptness in listing. There was equal interest among the group in reinstitution of the Documents Catalog and the 1909 Checklist of United States Public Documents, 1789-1909, as well as many requests for 
a checklist of Congressional hearings.

The first group of a series of microfilms of national and local gazettes for twelve Latin American countries was issued by the New York Public Library under a plan developed by the First Seminar on the Acquisition of Latin American Materials in 1956 and later supported by the Association of Research libraries. It is hoped that this program can be expanded to include gazettes of all countries of the world.

The Documents Expediting Project now has 430 participating libraries which support procurement and distribution to them of Federal documents not obtainable from the Superintendent of Documents. The project is operated by the Library of Congress under contract to the Joint Committee on Government Publications of four national library associations. It began publication of a Bulletin in 1951 .

Theses and dissertations. Access to theses and dissertations is far from satisfactory. There is no national listing of masters theses although there are innumberable long and short special lists issued by universities, libraries, scholarly journals, etc.

Dissertation Abstracts of doctoral dissertations had 27 doctoral-degree-granting universities in 1952 and now has 107 cooperating in supplying copies of dissertations for microfilming. A complete text of dissertations included can be obtained from University Microfilms, Inc., as a Xerox print on sulphite paper or microfilm. Doctoral Dissertations Accepted by American Universities was published continuously from 1934 through 1955 by the H. W. Wilson Company. Although broader in scope than its predecessor it was not complete, was slow in appearing, difficult to use, and costly to issue. In 1957, University Microfilms, Inc., began issuing it as an annual index to Dissertation Abstracts and to other doctoral dissertations granted by American universities. It is now appearing on time; its alphabetical arrangement by subject is easier to use than the previous arrangement by major fields with an alphabetical index to the subjects covered by it. All university dissertations, however, are not included in Dissertation Abstracts.

Translations. The great demand for translations of scientific literature has intensified the effort to find faster methods of translating and more effective ways of disseminating translations to those who may have use for them.

The translation center established by the Special Libraries Association in John Crerar Library is now the national depository for unpublished translations in all languages and is serving as an information center for the library. It published Translation Monthly from 19551958 , and continues to issue printed cata$\log$ cards for current scientific and technical material.

Since 1958, all translations from this center and from other sources such as the U. S. Joint Publications Research Service are listed, indexed, and abstracted by the Office of Technical Services in its semimonthly Technical Translations. The OTS also issues abstracts of those of the Joint Service on cards.

So much money is going into translating and the publishing of translations and their bibliographies that some concern has been felt by abstracting services lest the endowing institutions underestimate the contribution of abstracts to the availability of information.

Much attention has been given to the possibility and problems of mechanical translation, a common language as well as the hardware. Massachusetts Institute of Technology has been publishing a journal on the subject since 1954 entitled Machine Translation.

Four large western universities have concluded a National Symposium on Machine Translation involving representatives of each group active in the field, and the Rand Development Corporation and Western Reserve University in 1959 
sponsored an International Conference on a Common Language for Machine Searching and Translation.

Audio-visual materials. The processing and storage of audio-visual materials pose the most acute problems because of their physical properties. A Special Committee on the Bibliographical Control of AudioVisual Materials was established by the American Library Association in 1955. Its first work was to survey some 203 film, 46 public, 66 college and university, and 92 school libraries to ascertain the status of these materials. It recommended standardization of essential elements of cataloging; greater promptness on the part of the Library of Congress in publishing cards; attention to possible need for a subject heading list; preparation of a manual on handling; and study of the use made of audio-visual materials.

The single most complete bibliographical control of motion pictures and films is The National Union Catalog volume listing them which reproduces catalog cards printed by the Library of Congress. It includes all copyrighted films, all Canadian and U. S. films of educational and instructional value, and U. S. Government films, and contains a subject index. Rules for Pictures, Designs, and Other Two-dimensional Representations prepared by the Library of Congress and the ALA are exemplified in this volume and serve as a basis for uniform listing throughout the country.

Maps and atlases. The list of maps and atlases published in the United States which is submitted to Bibliographic cartographique internationale (Paris, A. Colin, 1936- ) is the most nearly complete listing of this material. Part 6 of the Catalog of Copyright Entries contains another important listing, largely commercially and privately printed maps.

The chief problem of the last half century in establishing effective control has been a basic disagreement on the cataloging of maps. One contention is that maps should be cataloged as books; the other that more important than the author of the map is the area, with subject, date, scale, size, title, projection, color, and physical characteristics of the map, in that order of importance. In practice these points of view are expressed by following the Library of Congress rules or the Boggs-Lewis system. Cataloging became a critical factor when through a depository program of the Army Map Service for distributing surplus war maps, a number of libraries acquired some fiftythousand maps in a very short time.

Music. Something of a renaissance appears to be taking place in music bibliography. However, there is a problem of disseminating information about the lists rapidly enough for research purposes.

Current national bibliographies for the field are of relatively recent date. In 1949 a Music Index to periodical literature was begun which, while not exhaustive, is comprehensive for music magazines. There is still a great need for a retrospective index to periodicals.

The journal, Notes, not only contains the best coverage of new books and music but now has a unique feature, an index to reviews of phonorecordings from domestic literature.

Recognizing the need for improvement of controls, the Music Library Association has set up a Committee on Periodical Indexing of Music.

Annual listings of music and phonorecords will be found in Part 5 of the Catalog of Copyright Entries and in $\mathrm{Li}$ brary of Congress Catalog-Music and Phonorecords: A Cumulative List of Works Represented by Library of Congress Printed Cards.

In 1952, the Library of Congress published Rules for the Descriptive Cataloging of Phonorecords.

Photoreproductions and other nonbook materials. So deeply has the use of photocopying, particularly microforms, penetrated the fabric of library, information, and documentation services that many older practices are being drastically 
changed. A few examples will illustrate the avenues of its diffusion. Microprint editions of American imprints before 1800 made by the American Antiquarian Society eventually including 35,000 titles; the Evans-Sabin Microcard Project issuing some 2,500 microcards per year; various newspaper microfilming projects such as the Association of Research Libraries national pool at the Midwest Inter-Library Center; numerous periodical microform projects some producing issues of journals as they appear; micro-reproduction of U. S. government documents and the records of the American Colonies, territories and states; manuscripts and archives widely filmed by private and governmental bodies such as the microfilming and indexing of the papers of twenty-three Presidents of the United States and of out-of-print books; dissertations, old telephone books, and groups of subject materials filmed in various forms. Wildlife Diseases, a new journal, receives initial publication on microcards. Microfilm for storage and electronic retrieval has made great progress.

Photocopying is used for acquisition, records, preparation as well as reproduction of bibliographies, documents, research notebooks, indexing, abstracting, etc.

The development of new copying processes and equipment has been so rapid that selection for use requires expert guidance. Various steps have or are being taken to cope with the problems. The National Microfilm Association has issued a Guide to Microreproduction Equipment and the ALA has set up a Copying Methods Section. The latter is considering several projects among which is the revision of the Directory of $M i$ crofilm and Photocopying Services, and a standard form for ordering such copies. The Association of Research Libraries has a new Committee on Micro-text Standards. The Special Libraries Association, with the other two, has a Joint
Committee on Fair Use in photocopying to work on another intricate problem. The American Standards Association has adopted standards for microfilm on reels and in strips, for film storage, and for size of paper sheets.

Xerography, an inexpensive method of producing a dry, positive, permanent, reproducible copy, is being widely used. A microfilm process (Kalfax) based on polymer chemistry which requires no darkroom developing is being used by the U. S. Department of Defense, Massachusetts Institute of Technology, and others. Enumeration of other equipment developed in the past ten years is impossible here.

Four national organizations have jointly received a grant to make a study of the bibliographical control of microcopies with particular attention to how their existence becomes known. An aid for this is the revision of the Union List of Microfilms, Supplement, 1949-1952 issued in 1953 by the Philadelphia Bibliographical Center and 215 other libraries in the United States and Canada.

A survey of medical and related fields has revealed that over seventy services are providing card-form publications including punched and microform cards.

Available opaque microforms appear in a new "Union List" which is neither a bibliography in the usual sense nor a union list but rather a compilation of 3242 entries supplied by publishers and provided with a subject index.

\section{INDEXING OF PERIOdicals}

Periodical indexing and abstracting services have a long and distinguished history in the United States from Poole to the present. However, the phenomenal increase in periodical literature since World War II has challenged the adequacy of indexing methods and procedures and diminished the usefulness of the indexes themselves as controls. To offset this, many services have made revolutionary changes with remarkable im- 
provement. In 1959 U. S. indexing and abstracting services covered a total of 556,267 items.

In 1958, at a conference convened by Biological Abstracts with the aid of the National Science Foundation, a National Federation of Science Abstracting and Indexing Services was founded to provide the best possible information services to scientists and technologists throughout the English-speaking world by means of cooperation, education, and research. The organization now has fourteen member services and is in the process of publishing a Guide to U.S. Indexing and Abstracting Services in Science and Technology (June, 1960) and a union list of periodicals abstracted by the member services.

A profusion of new indexing and abstracting services has been started for such subjects as law, psychoanalysis, medical diagnosis and treatment, tobacco, etc. Old ones, such as the longuseful H. W. Wilson Company's, have been changed. The Wilson indexes are in process of thorough revision under the joint review of users and publisher. The Industrial Arts Index was split into the Business Periodicals Index and the Applied Science and Technology Index and new titles indexed.

The deluge of literature has been felt most acutely in medicine and the physical sciences. The largest indexing service of the literature of a specific subject in the world, the Current List of Medical Literature (1950-1959) prepared by the National Library of Medicine, was indexing only about one half of the available material, missing possibly 110,000 articles of merit per year. A new Index Medicus (Jan. 1960- ) instituting a new system of indexing using a unit citation, the Listomatic camera, punched cards, and high speed sorters has replaced the Current List. It is expected to increase the yearly coverage to 180,000 articles in the next five years.

Chemical Abstracts (1907- ), the largest abstracting service, prepares eighty thousand abstracts per year from seven thousand journals, has made procedural innovations, utilized tape for recording index terms, and maintained a continuing study of terminology, machines, and systems.

The excellence of the subject indexes to the abstracts has been marred only by their delay in appearing. To correct this the Service has initiated a new publication Chemical Titles (1960- ) which contains a list of citations with all titles in English, a keyword index, an author index and a list of periodicals covered based on systematic examination of some 550 journals. The indexing is accomplished by use of a "Key-Word in Context" form prepared with an IBM 704 computer.

Nuclear Science Abstracts (1948- ) makes use of standard machines including IBM accounting-machine punched cards, coding and sorting machines, machine controlled photographing of cards (at a rate of 230 cards per minute), and photo-offset printing. This enables increased coverage at lower unit costs in less time. Approximately twenty-five thousand abstracts are produced per year.

Some think that the volume of literature and the cost of harnessing it with costly indexing services will eventually make the price to the consumer prohibitive. To the present time, this has not appreciably retarded the search, experimentation, and development of machines and systems for information retrieval.

At the beginning of the decade machines performed elementary sorting jobs. Today higher powered scanning machines are available, but none is fast enough or cheap enough to solve very many information searching problems. Speeds are being so greatly increased now that it is possible that scanning a million entries for the one wanted may some day be faster and cheaper than having the librarian use the card catalog in the usual way. With the development of 
the photoscopic disc much greater speed and storage capacity is in the offing. A single disc can hold as many as fifteen million bits of information.

However, a more hopeful development than machines which scan seriatim is the random access searching machine which utilizes a scheme similar to coordinate indexing. It is not dependent upon speed for its efficiency because it does not have to scan all the entries coded into the machine. The IBM RAMAC, which is an example of this machine, has a capacity for storing five million alphanumeric characters. The literature of experimentation and use of mechanized storage and retrieval is voluminous. For punched cards alone, a comprehensive bibliography on uses published in 1951 contained 276 entries. A 1958 revision contains 400 additional entries.

Relatively few applications of machines in information work have been made but they are increasing. The first edition of Punched Cards (1951) had 186 pages on practical applications. The second edition published in 1958, while by no means complete, had 295 pages of the same type and page size. So many mechanized devices are on the market that neither evaluation of the products nor of progress has been possible.

How information is used by the technician, chemist, engineer, biologist, historian, librarian is a perennial subject of study and discussion. Bibliographies, theses, and literature surveys have appeared on this subject in the last decade, but as yet no accurate generalizations can be made beyond the confines of the particular groups observed.

Production of machines of miraculous capabilities is considered the easier part of the work. The necessity of an overall theory of information as the basis of bibliographic organization is debated, but there is little argument about the indispensability of classification and language to the development of any satisfactory system of control. It is on this shoal that most experiments founder.

Attention to terminology and coding by documentalists and machine experts, and subject headings and classification by librarians has been accelerated. The former do not accept conventional library terms and hierarchical classes for storage and retrieval, and many librarians are questioning their own systems, reexamining them and seeking improvements. In 1952, the ALA Division of Cataloging and Classification and the School of Library Service at Columbia University held an Institute on the Subject Analysis of Library Materials at which dissatisfactions with, defenses of, and new developments in methods and systems of classification, subject cataloging, indexing, and other efforts to draw out the content of materials were aired. The term, "subject analysis," itself, was indicative of a different approach in library circles. The institute followed close upon serious questions raised in the $\mathbf{L}$ brary Quarterly as to the nature and purpose of subject catalogs in libraries.

Evidence of progress since that time is noted in the National Library of Medicine which has in press Medical Subject Headings for use equally in cataloging books and indexing periodicals. It will be kept up to date by interim revision sheets. Even the sixteenth edition of Dewey, used by 96 per cent of the public libraries in the country, reflects the changing concepts in organic and inorganic chemistry in two new schedules and in the use of modern terminology throughout all schedules.

Meantime documentalists and information specialists have not been idle. Techniques, methods, and schedules for devising terms and codes have appeared in ever increasing number with appropriate jargon to explain them. Many new words and new connotations for old ones have come into the vocabulary of documentalists and, to a lesser degree, librarians-descriptor, uniterm, trope, bit, symbolic logic, binary, coordinate index- 
ing, datamation, encode, etc. American Documentation published a dictionary of documentation terms in April 1960 listing over 400 .

All of this work takes time and money and many groups are working on the problems. Elements of organizational structures are appearing in various places - a new center, a new division, another committee. A Center for Documentation and Communication Research was established at Western Reserve University. It is engaged in basic and theoretical research on a theory of documentation and searching strategy; in carrying out experimental work in machine searching of literature on contracts from private and governmental agencies.

A Research Information Center and Advisory Service on Information Processing was established in 1959 by the National Science Foundation and the $\mathrm{Na}$ tional Bureau of Standards to make theoretical studies of storage and retrieval, the mechanization of procedures in the processing of information, natural languages and machine translation, evaluation of mechanized systems, machine recognition of patterns such as chemical structure diagrams, etc., in cooperation with industry, foundations, universities, professional groups, and the Federal Government. The National Science Foundation was, itself, founded in 1950 to support basic research and education and to foster the exchange of scientific information.

The Special Libraries Association created a Documentation Division. The term "documentation" was seldom used among librarians in the United States prior to this decade. There is still considerable disagreement as to what it is and a tendency to equate it with special librarianship.

The American Standards Association has defined and developed a standard for indexing.

A bill to create a Department of Science in the Government was before the
Congress and if passed as written would have "responsibility for development and utilization of the latest mechanical aids and new devices for collating, translating, abstracting, indexing, storing and retrieving scientific and technological information under the control of the Federal Government, and to coordinate such data available from other sources."

The United States Senate Committee on Government Operations made a study and evaluation of progress since 1958 in the development of science information processing and retrieval programs and systems established by federal agencies. Since its inception in 1947 the committee had been interested in coordinating government programs for the assembly, analysis, indexing, storage, retrieval, and dissemination of scientific information. The report of its survey has been issued in 283 pages by the Senate during the 2nd Session of the 86th Congress in 1960 under the title, Documentation, Indexing and Retrieval of Scientific Information.

Various types of indexes in depth are gaining favor. A condensation-pluscomment review similar to nineteenth century review and abstracting journals, and a further refinement in review and analysis, the yearly "progress in" several medical disciplines, and a Beilstein-type index to cardiovascular literature are examples.

Retrieval in even greater depth is to be obtained from the Human Relations Area Files for anthropology at Yale University and some sixteen other universities and government agencies which maintain photocopies of the files.

Means of identifying journals and their articles short of the above kinds of indexing and abstracting, while more elementary, are an essential part of existing controls. Such are the Monthly Index of Russian Accessions (1948- ), Southern Asia Accessions List (1952-

), East European Accessions Index (1951- ), and the Chemical Abstracts' 
quinquennial List of Periodicals Indexed. The magnitude of serial output may be better comprehended with the fact that the Library of Congress receives 100,000 different titles per year.

Research reports have given added impetus to the search for systems. These reports are acquired at the rate of 9758 per year by the Office of Technical Services, whose collection exceeds 163,000 on basic physical sciences, technology and shop practice, circulated to more than 100,000 per year. The Publications Board, also a government agency, has custody of German scientific reports from World War II, and, now, more than 100,000 Atomic Energy Commission reports. The reports held by the two agencies are listed and many abstracted in the OTS monthly U.S. Government Research Reports (1955- ) sent to five thousand subscribers. Copies may be obtained in photocopy, microfilm, and in its original form.

Two international conferences organized in the United States to discuss problems mentioned above were the International Conference on Scientific Information in 1958, for which one thousand observers were registered and seventy-five papers were analyzed, was sponsored by the National Science Foundation, the National Academy of Sciences, and the American-Documentation Institute, and was the successor to the Royal Society's Scientific Information Conference of 1948. The Conference was not constituted to pass resolutions but the preprints and proceedings are not only a record of present practices and problems, but point to next steps. A joint meeting of the special Libraries association and the Documentation Committee of NATO's Advisory Group for Aeronautical Research and Development convened in 1955.

\section{Training in Bibliography}

Professional education in librarianship and allied fields has lagged considerably behind that of other professions.
Various reasons are given for this, such as the very low salaries offered librarians for many years, their inability to develop the theoretical basis of a profession, the dichotomy in educational requirements imposed on the one hand by the public libraries and on the other by the college and research libraries, and the failure of librarians to sell themselves and their work to administrators at as high a price as others. The debate often obscures cause and effect.

Nevertheless, remarkable progress toward improvement of the educational level of the profession is observable in the past ten years. In 1951, the ALA adopted standards which raised required education for librarianship from the fourth year of college in library science for the degree of Bachelor of Library Science to a year's graduate work for a Master of Library Science.

Some 563 institutions in the United States are offering library science courses but only thirty give the fifth-year accredited program. The number of schools giving unaccredited work gives concern among those who have worked hardest to raise and achieve professional status for the field.

An effort is being made among accrediting bodies to devise undergraduate standards which will prepare for graduate study of library science and yet not restrict agencies from complying with local rules for certification in school and public libraries. The 1952 Standards for Library Science Programs in Teacher Education Institutions were revised by the ALA and incorporated by the American Association of Colleges for Teacher Education in its Standards for Accreditation of Teacher Education Institutions. The latter association was succeeded by the National Council for the Accreditation of Teacher Education in conjunction with which the ALA worked on a later standard adopted by the National Council. For a number of reasons the ALA will probably never serve as an accredit- 
ing agency for undergraduate schools. However, it will continue to work closely with the several college accrediting bodies.

A deep controversy has arisen over the fifth-year program and the efforts to accredit undergraduate schools. It is charged that "too many chiefs and not enough Indians" are being produced, that for many low-paid jobs it is unfair to expect applicants to have such expensive training and that consequently there are few applicants, etc. A variety of suggestions are made. Resolution is for the future.

One powerful stimulus to improvement of education is the demand for trained librarians, documentalists, and information officers. There are approximately three professional positions for each fifth-year graduate in librarianship in general and a many times greater number in the special library field. More than eighteen thousand librarians are needed. The number of staff members in academic libraries has increased 50 per cent in ten years.

Two factors loom large in the search for causes of this situation. The first, is the Library Services Act passed in 1956 which is to bring public library service to the rural areas of the United States. Millions of people who never before had library service now are receiving at least some. This entails new libraries and greatly extended service from existing libraries. The Act has been amended and renewed for a second five years and voted $\$ 7,500,000$ for the first year of the second period.

The second factor is the rapid growth of the population with the prospect of a doubling of the college freshman enrollment by 1965 . Colleges are expanding and many universities are establishing new campuses, often miles from parent institutions. This, too, means new and expanded library facilities and more trained librarians.
In spite of this, an alarming decline in library school enrollments characterized the middle 'fifties. They are gradually recovering and in the fall of 1959,1184 full-time students were registered for the MA and the 1917 part-time. Masters degrees granted in the school year 19581959 totaled 1453. However, recruiting for librarianship is a major effort on the part of all branches of the profession and further improvement is expected.

The picture is not all as dark as the foregoing would imply. In a survey of training for scientific documentation work submitted to the International Conference on Scientific Information it was revealed that a great many colleges and universities offer subject bibliography courses in science, technology, the humanities, and the social sciences. Of thirty-seven schools studied in the United States and Canada in 1957, twenty-six had a program of courses, a course, or a seminar in some aspect of special librarianship. The entire group had required bibliography courses with attention to the literature of science and technology, thirteen of which were separate required literature courses, and fourteen of which were elective. "Documentation" courses were offered in five, and "science documentation" in two; five have courses in medical bibliography; and agriculture, biology and pharmacy literature courses are offered in one each.

Since education is not confined to academic courses, it is relevant to note that there are fifteen national library associations in the United States which hold meetings, publish, grant scholarships, develop standards for service and training, and otherwise contribute to professional education without themselves regularly offering courses or seminars as do some European associations. In addition a number of libraries, information and documentation centers provide in-service training for library school graduates, or train subject specialists. 